\title{
Comparative Study between Synthetic and Natural Antioxidants of Banana, Mango and Orange Peels Extracts and their Effect on the Soybean and Olive Oils

\author{
Aly, A. A.; Nawal A. Tahoon and Jasmine M. Faid \\ Home Economics Department, Faculty of Specific Education, Benha University, Egypt
}

\section{ABSTRACT}

This study assayed to evaluate the effect of phenolic and flavonoids compound of banana, mango and orange peels extracts on some chemical properties of soybean and olive oils during storage period. Phenolic and Flavonoids compounds were determined by high performance liquid chromatographic method (HPLC) using ultraviolet (UV) detector set at $280 \mathrm{~nm}$ and $330 \mathrm{~nm}$, respectively. Soybean and olive oils storied (Six months) at room temperature $\left(20 \pm 2{ }^{\circ} \mathrm{C}\right)$ after additional $1200 \mathrm{ppm}$ banana, mango and orange peels extracts and compared with additional $200 \mathrm{ppm}$ of synthetic antioxidants (BHT \& BHA) The oils samples analyzed every month for acid, peroxide and iodine values during storage period. The results indicated that in the end of storage period acid and peroxide values of soybean and olive oils which treated with banana, mango and orange peels extracts $(1200 \mathrm{ppm})$ were lower than other treatments, while iodine value were higher. It can be concluded that the additional of banana, mango and orange peels extracts enhanced the acid, peroxide and iodine values of soybean and olive oils in the end of storage period.

keywords: Antioxidants- Soybean oil- Olive oil- Acid value- Peroxide value- Iodine number- Fruit peels.

\section{INTRODUCTION}

Fruit peels are one of the fruit wastes and it considered a major source of natural antioxidants (Gorinstein, et al. 1998), (Bocco et al. 1998), while the peeled powder of fruit may impart health benefits when used in functional food products, due to the low-coast of these residues we can use these peels as nutritional dietary supplements for low-income communities (Oliveira et al. 2009).

Banana is the second largest product after citrus fruit account for only around $16 \%$ of global world product. India is contributing $27 \%$ of the world for banana production (Mohapatra et al. 2010). Banana (Musaceae) enormous by-products are an excellent source of highly valuable raw materials for other industries (Padam et al. 2014). Banana peels is an abundant and low cost agricultural waste residue, it is easily available in large quantities, and it accounts for about $40 \%$ of the weight of the raw fruit and it is rich in protein, carbohydrates, various vitamins and mineral elements (Ramli et al. 2009), (Dhabekar and Chandak 2010). Banana peel is known by its local and traditional use to promote wound healing mainly from burns and to help overcome or prevent a substantial number of illnesses, as depression (Pereira and Maraschin 2015). Applications of bioactive constituents from banana peels should not be limited to nutraceuticals for direct human consumption, but must extend to further exploit as natural preservatives for foods (Mokbel and Hashinaga 2005).

In Egypt mangoes are the most popular fruits and are cultivated almost in the whole of the Nile valley and around the desert. There are several varieties grown in Egypt, the better known cultivars are alphonso, balady, pairi, mabroka, zebda, and succary (Elsoukkary et al. 2000). Egypt produced more than four million tons of mango fruit in 2004/2005 (Ministry of Agriculture 2005). Several million tons of mango wastes are produced annually from factories. Because mango is a seasonal fruit, about $20 \%$ of fruits are processed for products such as leather, puree, nectar, pickles and canned slices among others, which have worldwide popularity (Ashoush and Gadallah 2011). The main by- products of processing mangos are the peels, the seed and fibers. Approximately, $0.5 \%$ of world mango production is used to obtain derived products; therefor the amount of bio-waste produces by processing industries is estimated to be around 75 million tons worldwide (Dorta et al. 2012). Mango peel as a byproduct of mango processing industry could be a rich source of bioactive compounds, and enzymes such as protease, polyphenol oxidase, peroxidase, carotenoids, vitamins $\mathrm{C}$ and $\mathrm{E}$, dietary fibers, and carbohydrate content (Ajila et al. 2007), and these peels constitutes about $15-20 \%$ of total weight of mango fruit (Ajila and Rao 2013).

The sweet orange types (citrus sinesis) are widely grown throughout the world and provide the greatest fruit marketing production, the many known cultivars can be subdivided into three main groups as the acid less or sugar oranges: common oranges (also known as whit or blond oranges), navel oranges and blood or pigmented oranges (Nagy et al. 1997). Whole peel or rind (pericarp) amount to less than $40 \%$ of the citrus industrial wastes whole peel is used for such products as candied, marmalade, brined, or dried peel, bioflavonoids, limettin, tangeretin, and peel seasonings. Combined with the pulp residue, it is used in the manufacture of feed for animals, molasses, alcohols, syrups and or distilled oils. The citrus fruits peel consists of an exterior yellow peel (epicarp) called flavedo and an interior white syrups peel (mescocarp) called albedo (Soliman 2011).

Food preservation plays a vital role in driving the food industry by extending the shelf life of foods. Current trends of industry show increase awareness towards the drawbacks of synthetic chemical preservatives and opt for minimally processed food or employing natural techniques in food preservation (Tiwari et al. 2009). The free radicals found in the living organisms causes oxidative damage to different molecules such as lipids, proteins, nucleic acids and these are involved in the interaction phases of many degenerative diseases (Ajila et al. 2007a). The antioxidant capacity can be explored in food industry by using wastes as a source of antioxidants to prevent the 
rancidity and oxidation of lipids. In fact, in recent years, research has focused on fruit peels to extract natural and low-cost antioxidants that can replace synthetic additives such as butylatedhydroxyanisole (BHA) and butylatedhydroxytoluene (BHT) that might be carcinogenic and even toxic (Whysner et al. 1994).

Soybean oil is one of the most vegetable oils spread, it used directly in food. The use of soybean oil in Egypt had begun from the year 1976 (El-Agroudy et al. 2011).

Virgin olive oil is credited as being one of the many healthful components; it is reduced incidence of chronic inflammatory disease, and is rich in phenolic compounds and the health promoting benefits (Parkinson and Cicerale 2016), when compared to other vegetable oils such as sunflower, cottonseed, corn and soybean oil, olive oil has a significantly lower rate of alteration and it can be stored for 18 months or more (Frank 2011).

Olive oil seems that its biophenols may scavenge free radicals, attracting distinct attention due to their beneficial effects in many pathological conditions, such as cancer (Kouka et al. 2017), some of the most important biophenols found in olive oil with marked biological activities, are oleacein, oleocanthal, elenoic acid, oleuropein and its derivatives, hydroxytyrosol and tyrosol. These compounds have the ability to scavenge free radicals by donating them hydrogen atom or an electron by chelating metals (Montaño et al., 2016), (Lewandowska et al. 2013).

Consequently, this investigation aims to evaluate the chemical composition of banana, mango and orange peels, and effect of phenolic and flavonoids content of banana, mango and orange peels extracts on some chemical properties of olive and soybean oils during storage period.

\section{MATERIALS AND METHODS}

\section{Materials}

Bananas (Musaceae), mango zebda (Mangifera indica L.), orange peels (citrus sinesis), soybean (Glycine max), and olive oils (Olea europaea) were obtained from local market in Egypt. Chemicals were purchased from Elgomhoria Company, Cairo, Egypt.

\section{Methods}

Banana, mango and orange peels were cleaned from extraneous matter and properly washed with tab water, then dried in air-oven for $24 \mathrm{~h}$ at $40{ }^{\circ} \mathrm{C}$ and then crushed into fine powder.

The dried banana, mango and orange peels ground in a blender to form powder, thereafter, $10 \mathrm{~g}$ of the powder macerated in $100 \mathrm{ml}$ absolute ethanol and the extraction repeated three times. The extracts filtered through "Whatman" filter paper (No. 40) and concentrate in a rotary evaporator under reduced pressure.

Soybean and olive oils stored (Six months) at room temperature $\left(20 \pm 2 \mathrm{C}^{\circ}\right)$ after additional $1200 \mathrm{ppm}$ banana, mango and orange peels extracts and $200 \mathrm{ppm}$ synthetic antioxidants (BHT \& BHA). Control soybean and olive oils and treated samples with extracts analyzed every month for acid, peroxide and iodine values during storage period.

\section{Gross chemical composition:}

Moisture, crude protein, crude lipids, ash and crude fiber content of the banana, orange and mango peels were determined according to the method described by (AOAC 2000).

Carbohydrates content was calculated by difference from the following equation:

Carbohydrates content $\%=100-($ Protein +

Moisture + Ash + Lipids + Fiber)

Chemical properties of oils:

Acid, peroxide and iodine values were determined according to (AOAC 2000).

Determination of Flavonoids Compounds:

Flavonoids compounds were determined by HPLC according to the method of (Mattila et al. 2000).

\section{Determination of phenolic compounds:}

Phenolic compounds were determined by HPLC according to (Goupy et al. 1999).

\section{Statistical analysis:}

The statistical evaluation of the mean \pm stander deviation data was compared using one-way analysis of variance (ANOVA) according to (Zar 1984).

\section{RESULTS AND DISCUSSION}

\section{1- Gross chemical composition of banana, orange and mango peels.}

Table (1) shows the gross chemical composition of banana, orange, and mango peels. It can be noticed that the moisture, crude protein, fat, ash, fiber and carbohydrate contents for banana peel were 8.125, $7.438,3.570,7.800,13.05$ and $31.858 \%$ respectively. Such results are in agreement with those obtained by (Marconi et al. 1997), (Chen et al. 2011) and (Kurhade et al. 2015). While chemical compositions of orange peels were $10.945,6.300,3.775,2.200,9.07$ and $21.34 \%$, such results are in agreement with those obtained by (Soliman 2011). Moreover chemical composition of mango peel was $8.450,3.850,6.330$, $8.050,11.98$ and $30.21 \%$. These results are in agreement with those obtained by (Larrauri and Cerezal 1993) and (Mostafa 2006).

Table 1. Chemical composition of banana, orange and mango peels.

\begin{tabular}{lccc}
\hline$\%$ & Banana peel & Orange peel & Mango peel \\
\hline Moisture & $8.125 \pm 0.709$ & $10.945 \pm 0.099$ & $8.450 \pm 0.058$ \\
Crude protein* & $7.438 \pm 0.226$ & $6.300 \pm 1.134$ & $3.850 \pm 0.143$ \\
Total lipids* & $3.570 \pm 0.159$ & $3.775 \pm 0.689$ & $6.330 \pm 0.242$ \\
Ash content* & $7.800 \pm 0.216$ & $2.200 \pm 0.183$ & $8.050 \pm 0.129$ \\
Fiber* & 13.05 & 9.07 & 11.98 \\
Carbohydrates* & 31.858 & 21.345 & 30.21 \\
\hline
\end{tabular}

Values are means of four replicates \pm stander deviation

*On dry weight basis

\section{2- Flavonoids content of banana, orange and mango peels extracts}

Table (2) show the flavonoids content of banana, orange and mango peels extracts. From this table, it could be noticed that hispertin is the predominant flavonoid compound (247.36 ppm) in banana peel extract, followed by rutin (198.07 ppm), these results are in agreement with (Anal et al. 2014). Concerning 
orange peels extract, it was found that these peels contain more contents of flavonoids than those present in banana peels, the predominant compound is hisperidin (2957.43) followed by rosmarinic and quercetrin (992.15, $922.10 \mathrm{ppm}$ respectively), these results are in agreement with (Sawalha et al. 2009). Mango peel extract contains the least flavonoid compounds and the predominant flavonoid compound hisperidin (1421.29 ppm).

Table 2. Flavonoids content of banana, orange and mango peels extracts (ppm).

\begin{tabular}{lccc}
\hline Flavonoids & $\begin{array}{c}\text { Banana } \\
\text { peel extract }\end{array}$ & $\begin{array}{c}\text { Orange } \\
\text { peel extract }\end{array}$ & $\begin{array}{c}\text { Mango peel } \\
\text { extract }\end{array}$ \\
\hline Luteolin & 9.85 & 207.07 & 145.97 \\
Narengin & 36.77 & 510.78 & 239.36 \\
Rutin & 198.07 & 771.97 & 1181.38 \\
Hisperidin & 73.29 & 2957.43 & 1421.29 \\
Rosmarinic & 46.17 & 992.15 & 297.85 \\
Quercetrin & 64.07 & 922.10 & 155.14 \\
Quercetin & 115.47 & 496.16 & 81.08 \\
Hispertin & 247.36 & 800.10 & 51.57 \\
Kampferol & 36.92 & 77.29 & 95.23 \\
Apegnin & 8.22 & 85.13 & 10.55 \\
\hline
\end{tabular}

3- Phenolic compounds of banana, orange and mango peels extracts

Table (3) illustrates the phenolic compounds of banana, orange and mango peels extracts. From this table it could be noticed that salycillic is the predominant flavonoid compound (735.23 ppm) in banana peel extract followed by pyrogallol (706.77 ppm), these results are confirmed by (Pereira and Maraschin, 2015).

Table 3. Phenolic content of banana, orange and mango peels extracts (ppm).

\begin{tabular}{lccc}
\hline $\begin{array}{l}\text { Phenolic } \\
\text { Compounds }\end{array}$ & $\begin{array}{c}\text { Banana } \\
\text { peel } \\
\text { extract }\end{array}$ & $\begin{array}{c}\text { Orange } \\
\text { peel } \\
\text { extract }\end{array}$ & $\begin{array}{c}\text { Mango peel } \\
\text { extract }\end{array}$ \\
\hline Gallic & 110.72 & 80.02 & 2331.04 \\
Pyrogallol & 706.77 & 943.86 & 13510.61 \\
4-Amino-benzoic & 35.25 & 114.26 & 207.04 \\
3-OH-Tyrosol & 236.39 & 670.61 & 1670.16 \\
Protocatchuic & 254.92 & 1515.43 & 2238.85 \\
Chlorogenic & 308.12 & 802.02 & 1966.51 \\
Catechein & 79.96 & 512.61 & 3951.10 \\
Catechol & 30.59 & 266.87 & 360.03 \\
Caffeine & 23.45 & 440.35 & 336.87 \\
P-OH-benzoic & 96.23 & 581.21 & 996.11 \\
Caffeic & 178.00 & 250.13 & 1813.56 \\
Vanillic & 77.51 & 146.05 & 290.15 \\
p-coumaric & 47.00 & 349.12 & 529.03 \\
Ferulic & 93.82 & 429.86 & 210.85 \\
Iso-ferulic & 19.72 & 84.33 & 125.03 \\
Reversetrol & 18.94 & 202.90 & 162.58 \\
Ellagic & 28.54 & 308.77 & 1029.48 \\
E-vanillic & - & - & 4234.46 \\
Alpha-coumaric & 65.74 & 210.42 & 372.88 \\
3,4,5-methoxy-cinnamic & 89.29 & 234.57 & 252.43 \\
Coumarin & 14.60 & 95.17 & 20.21 \\
Salycillic & 735.23 & 1363.45 & 1340.83 \\
\hline & & &
\end{tabular}

Concerning orange peels extract, it was found that these peels contain more contents of flavonoids than those present in banana peels, the predominant compound is protocatchuic (1515.43 ppm) followed by salycillic (1363.45) ppm, the same trend of results are in agreement with (Ma et al. 2009). Mango peel extract contain the highest flavonoid compounds, the predominant compound is pyrogallol (13510.61), followed by e-vanillic (4234.46), these results are in agreement with (Tunchaiyaphum et al. 2013) and (Saafan 2014).

\section{4-Changes in soybean oil treated with peel extracts} during storage for 6 months

From data tabulated in table (4) it can be noticed that the acid value of soybean oil (control sample) increased from 0.156 at zero time to 0.549 at the end of storage period, these results are confirmed by (Williams 1966). Moreover the same table (4) showed the acid values of soybean oil treated with synthetic and natural antioxidants gives almost similar results in the end of storage period and a significant $(\mathrm{P} \leq 0.05)$ reduced the whole acid values compared with control sample. These results are confirmed by (Race 2009). It can be assayed that antioxidants inhibit or retard the oxidation of lipid through its action as hydrogen or electron donors. Therefore, antioxidant interferes with the radical chain reaction by forming non-radical compounds that will not propagate further radical reaction (Madsen et al. 1997). Also from results in table (4) it can be noticed that the peroxide value of soybean oil (control sample) increased from $2.500 \mathrm{Meq} / \mathrm{kg}$ oil at zero time to 8.900 $\mathrm{Meq} / \mathrm{kg}$ oil at the end of storage period. These results are confirmed by (Saafan 2014). Moreover the same table 4 showed the peroxide values of soybean oil treated with synthetic and natural antioxidants gives almost similar results in the end of storage period and a significant $(\mathrm{P} \leq 0.05)$ reduced the whole of peroxide values compared with control sample. It can be explained that antioxidants are scavengers of oxygen radicals or hydrogen radicals that have been proposed to be agents that attack poly unsaturated fatty acids in cell membranes, giving rise to lipid peroxidation (Zien ElDien 1999). From the same table (4) showed the iodine value of soybean oil (control sample) decreased from 135.994 at zero time to 122.881 at the end of storage period which appears the oxidation of control sample. These results are confirmed by (Williams 1966). Moreover, it can be concluded that the iodine values of soybean oil treated with synthetic and natural antioxidants gives almost similar results and a significant $(\mathrm{P} \leq 0.05)$ increases the whole iodine values compared with control sample in the end of storage period. These results are confirmed by (Ferri et al. 2005).

5- Changes in olive oil treated with peel extracts during storage for 6 months.

From data revealed in table (5) it can be noticed that the acid value of olive oil (control sample) increased from (0.218) at zero time to (0.611) at the end of storage period, moreover, the acid value of synthetic and natural antioxidants gives almost similar results and a significant $(P \leq 0.05)$ reduced the acid values compared with control sample. 
Table 4. Changes in soybean oil treated with peel extracts during storage for 6 months.

\begin{tabular}{|c|c|c|c|c|c|c|c|c|c|c|c|c|c|}
\hline \multirow{2}{*}{ 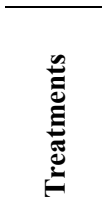 } & \multirow{2}{*}{ 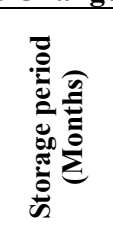 } & \multicolumn{4}{|c|}{ Acid value } & \multicolumn{4}{|c|}{ Peroxide value } & \multicolumn{4}{|c|}{ Iodine value } \\
\hline & & $\mathbf{0}$ & 2 & 4 & 6 & $\mathbf{0}$ & 2 & 4 & 6 & $\mathbf{0}$ & 2 & 4 & 6 \\
\hline \multirow{2}{*}{ Control } & & $0.156^{\mathrm{a}} \pm$ & $0.262^{a}=$ & $=0.374^{\mathrm{a}} \pm$ & $0.549^{\mathrm{a}} \pm$ & $2.500^{\mathrm{a}} \pm$ & $=4.567^{\mathrm{a}} \pm$ & $6.733^{\mathrm{a}} \pm$ & $8.900^{\mathrm{a}} \pm$ & $135.99^{b} \pm$ & $\pm 130.28^{b}$ & $\pm 127.11^{b} \pm$ & $122.88^{b} \pm$ \\
\hline & & 0.01 & 0.02 & 0.02 & 0.01 & 0.02 & 0.01 & 0.01 & 0.00 & 0.37 & 3.72 & 0.73 & 1.60 \\
\hline \multirow{2}{*}{ BHT } & & $0.150^{\mathrm{a}} \pm$ & $0.237^{\mathrm{a}} \pm$ & $0.337^{\mathrm{a}} \pm$ & $0.449^{b} \pm$ & $2.467^{\mathrm{a}} \pm$ & $=4.033^{\mathrm{b}} \pm$ & $=5.600^{\mathrm{c}} \pm$ & $7.533^{\mathrm{b}} \pm$ & $136.21^{\mathrm{b}} \pm$ & $\pm 135.15^{\mathrm{a}}$ & $\pm 132.18^{\mathrm{a}} \pm$ & $129.44^{\mathrm{a}} \pm$ \\
\hline & & 0.02 & 0.01 & 0.002 & 0.03 & 0.01 & 0.01 & 0.02 & 0.04 & 0.97 & 1.68 & 1.83 & 1.10 \\
\hline \multirow{2}{*}{ BHA } & & $0.162^{\mathrm{a}} \pm$ & $0.243^{\mathrm{a}}=$ & $=0.343^{\mathrm{a}} \pm$ & $0.443^{\mathrm{b}} \pm$ & $2.533^{\mathrm{a}} \pm$ & $=4.100^{\mathrm{b}} \pm$ & $=5.633^{\mathrm{c}} \pm$ & $7.567^{\mathrm{b}} \pm$ & $137.47^{\mathrm{a}} \pm$ & $\pm 134.93^{\mathrm{a}}$ & $\pm 132.39^{\mathrm{a}} \pm$ & $=129.65^{\mathrm{a}} \pm$ \\
\hline & & 0.01 & 0.04 & 0.02 & 0.02 & 0.01 & 0.02 & 0.01 & 0.04 & 0.73 & 2.04 & 1.47 & 0.73 \\
\hline \multirow{2}{*}{\multicolumn{2}{|c|}{ BPE (1200)PPM }} & $0.156^{\mathrm{a}} \pm$ & $0.243^{\mathrm{a}}=$ & $=0.355^{\mathrm{a}} \pm$ & $0.461^{\mathrm{b}} \pm$ & $2.533^{\mathrm{a}} \pm$ & $=4.267^{\mathrm{b}} \pm$ & $=5.967^{b} \pm$ & $7.967^{\mathrm{b}} \pm$ & $136.20^{\mathrm{b}} \pm$ & $\pm 134.30^{\mathrm{a}}$ & $\pm 131.34^{\mathrm{a}} \pm$ & $128.59^{\mathrm{a}} \pm$ \\
\hline & & 0.02 & 0.00 & 0.00 & 0.01 & 0.02 & 0.01 & 0.01 & 0.01 & 0.37 & 2.04 & 1.10 & 0.37 \\
\hline \multirow{2}{*}{\multicolumn{2}{|c|}{ OPE (1200)PPM }} & $0.150^{\mathrm{a}} \pm$ & $0.237^{\mathrm{a}}=$ & $=0.349^{\mathrm{a}} \pm$ & $0.455^{\mathrm{b}} \pm$ & $2.567^{\mathrm{a}} \pm$ & $=4.033^{\mathrm{b}} \pm$ & $=5.767^{\mathrm{c}} \pm$ & $7.767^{\mathrm{b}} \pm$ & $136.20^{\mathrm{b}} \pm$ & $\pm 135.36^{\mathbf{a}}$ & $\pm 132.40^{\mathrm{a}} \pm$ & $129.86^{\mathrm{a}} \pm$ \\
\hline & & 0.02 & 0.01 & 0.01 & 0.01 & 0.01 & 0.01 & 0.02 & 0.05 & 0.37 & 1.32 & 1.60 & 0.73 \\
\hline \multirow{3}{*}{ MPE } & & $0.156^{\mathrm{a}} \pm$ & $0.249^{\mathrm{a}}=$ & $=0.299^{\mathrm{b}} \pm$ & $0.468^{\mathrm{b}} \pm$ & $2.467^{\mathrm{a}} \pm$ & $4.167^{\mathrm{b}} \pm$ & $=5.833^{\mathrm{c}} \pm$ & $7.833^{\mathrm{b}} \pm$ & $136.20^{\mathrm{b}} \pm$ & $\pm 134.51^{\mathrm{a}}$ & $\pm 131.55^{\mathrm{a}} \pm$ & $=128.80^{\mathrm{a}} \pm$ \\
\hline & 00)PPI & 0.02 & 0.01 & 0.08 & 0.02 & 0.02 & 0.03 & 0.01 & 0.01 & 0.37 & 1.68 & 1.32 & 0.63 \\
\hline & & 0.031 & 0.033 & 0.065 & 0.034 & 0.157 & 0.157 & 0.139 & 0.297 & 1.03 & 3.95 & 2.47 & 1.68 \\
\hline
\end{tabular}

Values are means of three replicates \pm stander deviation. LSD: Least significant differences. Data were analyzed by ANOVA (Single factor $P \leq \mathbf{0 . 0 5})$

(BHA): butylatedhydroxyanisole (BHT): butylatedhydroxytoluene (BP): Banana peel (OP): Orange peel (MP): Mango peel

And the peroxide value of olive oil (control sample) increased from (3.533 Meq/kg oil) at zero time to $(9.800 \mathrm{Meq} / \mathrm{kg}$ oil) at the end of storage period., while the peroxide values of olive oils treated with synthetic and natural antioxidants a significant $(\mathrm{P} \leq$ $0.05)$ reduced compared with control sample. The same table 5 concluded that orange peel extract (OPE) 1200 $\mathrm{ppm}$ is the best treatment to retard the acid and peroxide values of olive oils in the end of storage period compared with other peel extracts, these retardation might be due to the effects of fruit peel extracts (flavonoids and phenols compounds) on oxidation of oils during storage, which retard the initial oxidation processes, these results are in agreement with (Kamran et al. 2009). From table (5) it can be noticed that the iodine value of olive oil (control sample) decreased from (92.849) at zero time to (79.101) at the end of storage period. These trends of results are in agreement with (Karleskind, 1992). Moreover iodine values of olive oil treated with synthetic and natural antioxidants gives almost similar results and a significant $(\mathrm{P} \leq 0.05)$ increased the whole values of iodine value compared with control sample in the end of storage period. These results are confirmed by (Ferri et al. 2005) and (Frankel et al. 1996).

Table 5. Changes in olive oil treated with peel extracts during storage for 6 months.

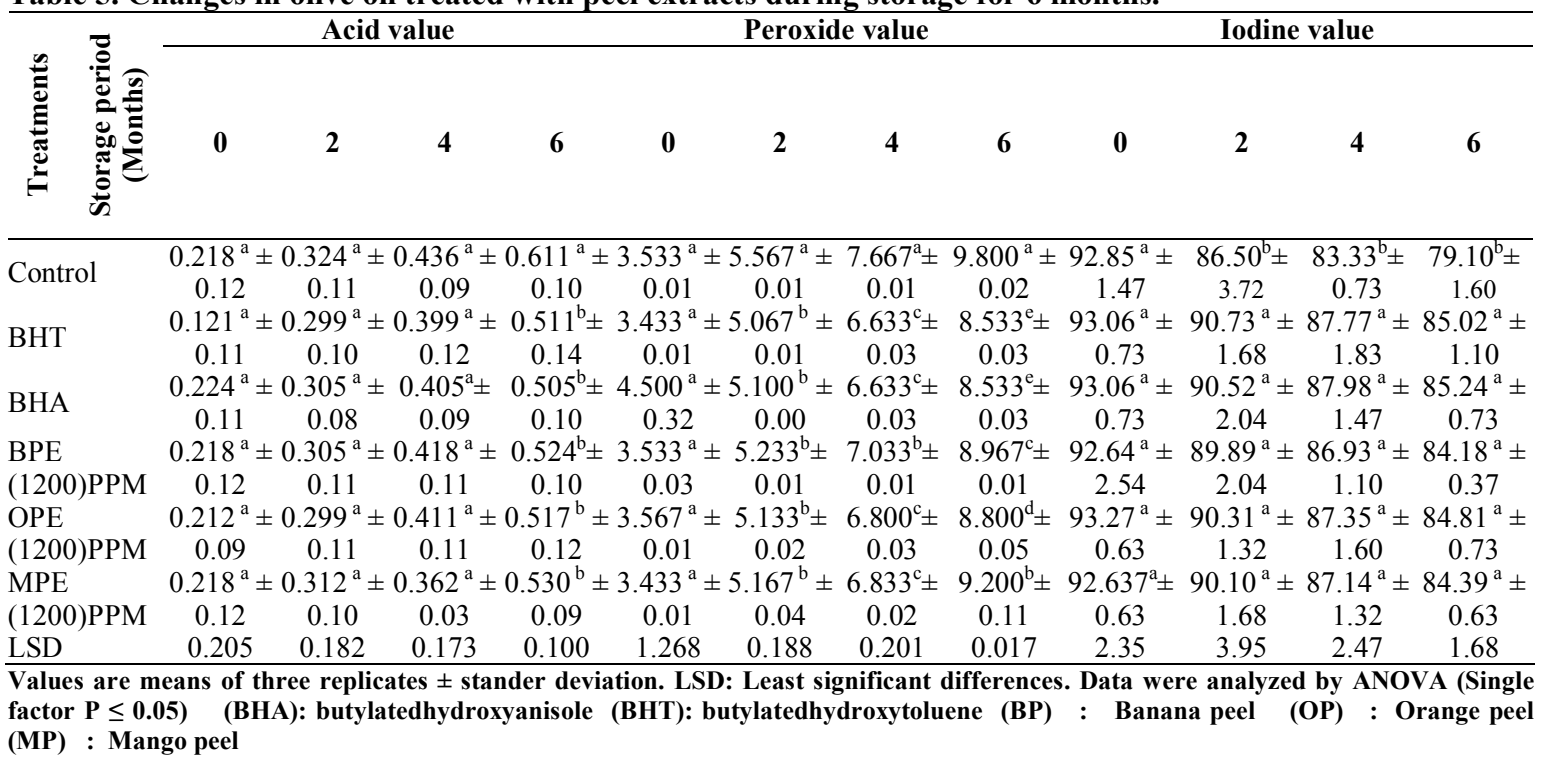

\section{CONCLUSION}

It could be concluded that addition of banana, orange and mango peel extracts to soybean and olive oils improved their qualities during storage period. These extracts can be used as natural antioxidants to retard the oxidative deterioration of oils. 


\section{REFERENCES}

Ajila, C.M. and Rao, P.U. (2013). Mango peels dietary fiber: Composition and associated bound phenolics. Journal of functional foods 5:444-450.

Ajila, C.M., Naidu, K.A., Bhat, S.G. and Rao, P.U. (2007a). Bioactive compounds and antioxidant potential of mango peel extract. Food Chemistry 105: 982-988.

Ajila, C.M., Bhat, S. G. and Rao, P.U. (2007b). Valuable components of raw and ripe peels from two Indian mango varieties. Food Chemistry, 102: 1006-1011.

Anal, A. Jaisanti, S. and Noomhorm, A. (2014). Enhanced yield of phenolic extracts from banana peels (Musa acuminata Colla AAA) and cinnamon barks (Cinnamomum varum) and their antioxidative potentials in fish oil. J Food Sci Technol. 51(10):2632-2639.

A.O.A.C.(2000).Official Methods of Analysis. Association of Official Analytical Chemist., EUA.

Ashoush, I.S. and Gadallah, M.G.E. (2011). Utilization of Mango Peels and Seed Kernels Powders as Sources of Phytochemicals in Biscuit. World Journal of Dairy and Food Sciences, 6 (1): 35-42.

Bocco, A., Cuvelier, M.E., Richard, H. and Berset, C. (1998). Antioxidant activity and phenolic composition of citrus peel and seed extracts. J Agric Food Chem., 46: 2123-2129.

Chen, X., Wei, G., Zhang, J., and Dong, Y. (2011). Efficient production of glutathione using hydrolyzate of banana peel as novel substrate. Korean J. Chem. Eng., 28(7): 1566-1572.

Dhabekar, A. and Chandak, A. (2010). Utilization of banana peels and beet waste for alcohol production. Asiatic journal of biotechnology resources, 1:8-13.

El Agroudy, N., Zaghlol, E.A., Mokhtar, S. and El gebaly, M. (2011). An economic study of the production of soybean in Egypt. Agriculture and Biology Journal of North America, 2:221-225.

El soukkary, F.A., El sahn, M.A. and Mohamed, H.M. (2000). Physico-chemical and nutritional evaluation of mango seed kernel and its utilization for pan bread supplementation. Zagazig Journal of Agriculture and Research, 27: 1319-1342.

Ferri, R.A., Vanessa, O. and Scabio, A. (2005). Oxidative stability of biodiesel from soybean oil fatty acid ethyl esters. Sci. Agric. (Piracicaba, Braz), (62)291-295.

Frankel, E.N., Huang, S.W., Aeschbach, R. and Rrior, E. (1996). Antioxidant activity of a Rosemary extract and its constituents, Carnosic acid, Carnosol and Rosemarinic acid in Bulk oil and oil-in-water emulsion J.Agric.Food Chem.,44: 131-135.

Gornistein, S., Kulasek, G., Bartnikowska, E., Leontowicz, M., Morawiec, M., Zemser, M. and Trakhtenberg, S. (1998). The influence of persimmon peel and persimmon pulp on the lipid metabolism and antioxidant activity of rats fed cholesterol. J. Nutr. Biochem., 9: 223-227.

Goupy, P., Hugues, M., Biovin, B. and Amiot, M.J. (1999). Antioxidant Composition and activity of barley (Hordeum yulgare) and malt tracts and of isolated phenolic compounds. J. Sci. Food Agric.,79: 16251634.
Kamran, G., Youcef, G. and Ebrahimzadeh, M.A., (2009). Antioxidant activity, phenol and flavonoid contents of 13 Citrus species peels and tissues. Pakistan Journal of Pharmaceutical Sciences 22 (3), 277-281.

Karleskind, A. (1992). Manuel des corps gras. Vol1.

Kouka, P., Priftis, A., Stagos, D., Angelis, A., Stathopoulos, P., Xinos, N., Skaltsounis, A.L., Mamoulakis, C., Tsatsakis, A.M., Spandidos, D.A. and Kouretas, D. (2017). Assessment of the antioxidant activity of an olive oil total polyphenolic fraction and hydroxytyrosol from a Greek Olea europea variety in endothelial cells and myoblasts. Int $\mathrm{J}$ Mol Med. 40:703-712.

Kurhade, A., Patil, S., Sonawane, S., Waghmare, J. and Arya, S. (2015). Effects of Banana peel powder on bioactive constituents and microstructural quality of chapatti- unleavened Indian flat bread. Journal of Food Measurement and Characterization, DOI: 10.1007/s11694-015-9273-0.

Larrauri, J.A. and Cerezal, P. (1993). Characterization de losresiduos different varied des de mango. Alimentaria, 242:89-92.

Lewandowska, U., Szewczyk, K., Hrabec, E., Janecka, A. and Gorlach, S. (2013). Overview of metabolism and bioavailability enhancement of polyphenols. J Agric Food Chem., 61: 12183-12199.

Ma, Y.Q., Chen, J.C., Liu, D.H. and Ye, X.Q. (2009). Simultaneous extraction of phenolic compounds of citrus peel extracts: effect of ultrasound. Food Chem. 16(1):57-62.

Madsen, H.L., Bertelsen, G. and Skibsted, L.H. (1997). In Antioxidative activity of spices and spice extracts. Elsevier Science, 14. Pp. 177.

Marconi, E., Ruggeri, S. and Carnovale, E. (1997). Chemical evaluation of wild under-exploited Vigna spp. Seeds. Food Chem. 59: 203-212.

Mattila, P., Astola, J. and Kumpulainen, J. (2000). Determination of flavonoids in plant material by HPLC with diode-array and electro-array detections. J. Ajric. Food Chem., 48: 5834-5841.

Ministry of Agriculture, (2005). Cultivated area and annual production of mango fruits in Egypt. Agriculture Economic Department, Ministry of Agriculture, Cairo, Egypt.

Mohapatra, D., Mishra, S. and Sutar, N. (2010). Banana and its utilization: an overview. Journal of Scientific and Industrial Research, 69: 323-329.

Mokbel, M.S. and Hashinaga, F. (2005). Antibacterial and antioxidant activities of banana (Musa AAA Cavendish cv.) fruit peels. Am. J. Biochem. Biotechnol., 1(3):125-131.

Montaño, A., Hernández, M., Garrido, I., Llerena, J.L. and Espinosa, F. (2016). Fatty acid and phenolic compound concentrations in eight different monovarietal virgin olive oils from extremadura and the relationship with oxidative stability. Int J Mol Sci 17: 17.

Mostafa, M.Z. (2006). Studies on Utilization of Food Processing Wastes. M.Sc. Thesis. Faculty of Agric., Mansoura Univ., Egypt. 
Nagy, N., Shaw, P. and Velduis, M. (1977). Citrus science and technology. A.V.I. Book, Wesrt Port, New York.

Oliveira, A.C., Valentimb, I.B., Silvac, C.A., Henriques, E.J., de Barrose, B.M., Manod, C.M. and Goularta, M.O. (2009). Total phenolic content and free radical scavenging activities of methanolic extract powders of tropical fruit residues. Food Chemistry, 115 (2): 469-475.

Osawa, T., Katsuzaki, H., Hagiwara, Y., Hagiwara, H. and Shibamoto, T. (1992). A novel antioxidant isolated from young green Barler leaves. J. Agric. Food Chem., 40: 1135-1138.

Padam, B.S., Tin, H.S., Chye, F.Y. and Abdullah, M.I. (2014). Banana by-products: an under-utilized renewable food biomass with great potential. J Food Sci. Technol. 51(12):3527-3545.

Parkinson, L. and Cicerale, S. (2016). The Health Benefiting Mechanisms of Virgin Olive Oil Phenolic Compounds. Molecules, 16: 21(12).

Pereira, A. and Maraschin, M. (2015). Banana (Musa spp) from peel to pulp: ethnopharmacology, source of bioactive compounds and its relevance for human health. J. Ethnopharmacol, 160: 149-163.

Race, S. (2009). The truth about BHA, BHT, TBHQ and other antioxidant used as food additives. World applied sciences journal 30(14):233-246.

Ramli, S., Alkarkhi, A.F.M., Yong, Y.S. and Easa, A.M. (2009). Utilization of banana peel as a functional ingredient in yellow noodle. Asian J Food AgroIndustry 2:321-329.

Saafan, E. E. (2014). Studies on stability of oils .M.Sc. Thesis. Faculty of Agric., Mansoura Univ., Egypt.
Sawalha, S.M.S., Arráez-Román, D., Segura-Carretero, A. and Fernández-Gutiérrez, A. (2009). Quantification of main phenolic compounds in sweet and bitter orange peel using CE-MS/MS. Food Chemistry 116, 567-574.

Soliman, F.M. (2011). Technological, chemical and biological studies on some fruits by-product. M.Sc. Thesis, Faculty of Agric. Mansoura Univ. Egypt, 165.

Tiwari, B.K., Valdramidis, V.P., O’Donnel, C.P., Muthukumarappan, K., Bourke, P. and Cullen P.J. (2009). Application of natural antimicrobials for food preservation. J Agric. Food Chem., 57:5987-6000.

Tunchaiyaphum, S., Eshtiaghi, M. N. and Yoswathana, N. (2013). Extraction of Bioactive Compounds from Mango Peels Using Green Technology. International Journal of Chemical Engineering and Applications, 4:194-198.

Whysner, J., Wang, C.X., Zang, E., Iatropoulos, M.J. and Williams, G.M., (1994). Dose response of promotion of butylated hydroxyanisole in chemically initiated tumors of the rat for stomach. Food and Chemical Toxicology 32, 215-222.

Williams, K.A, (1966). Oils fats and fatty foods.4th ed. Churchill, Inc., London.

Zar, J.H. (1984). Biostatistical analysis. Prentice Hall,Englewood, N.J.,pp. 718.

Zien El-Dien, G. (1999). Chemical and technological studies on oil and oil products and some of its stability. Ph.D. Thesis, Mansoura Univ., Egypt.

\section{دراسة مقارنة بين مضادات الأكسدة الصناعية والطبيعية لمستخلصات قشور المـوز والمـانجو والبرتقال وتأثيرهـا

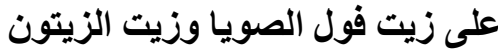

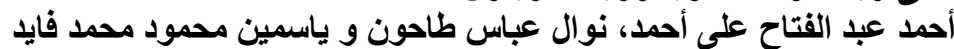

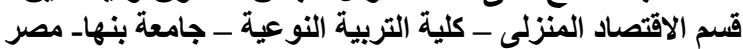

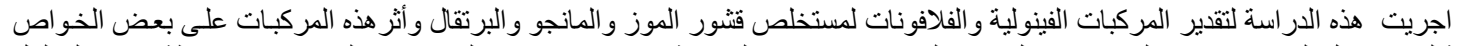

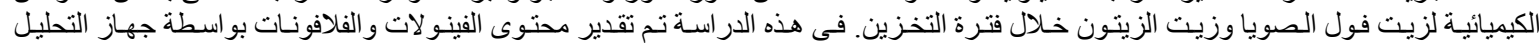

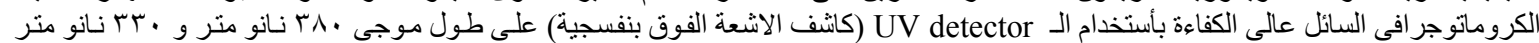

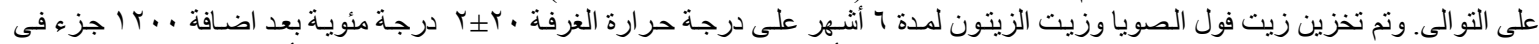

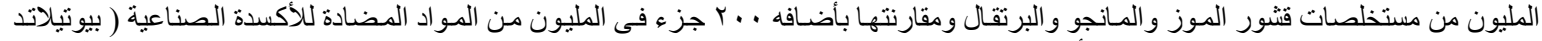

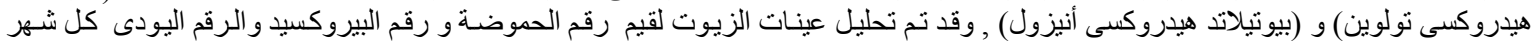

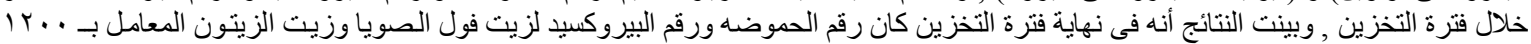

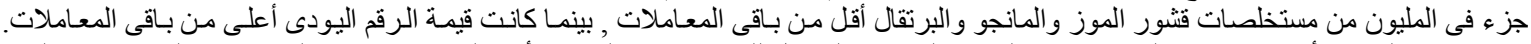

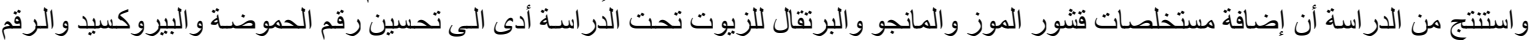

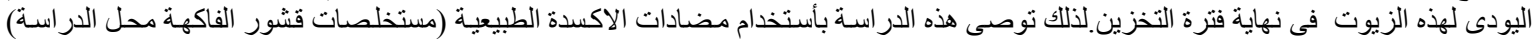

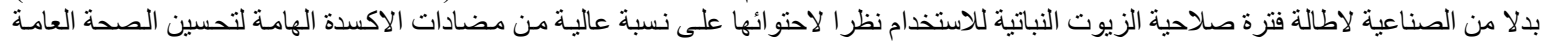

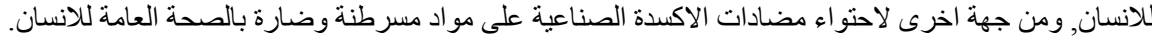

